\title{
Studies in Man With Cold-Recombinant Influenza Virus (H1N1) Live Vaccines
}

\author{
P. Reeve, Batia Gerendas, A. Moritz, E. Liehl, C. Kunz, H. Hofmann, and \\ H.F. Maassab \\ National Institute for Biological Standards, London (P.R.), Sandoz Research Institute, \\ Vienna (B.G., A.M., E.L.), Institut für Virologie, Universität Wien (C.K., H.H.), and \\ University of Michigan, Ann Arbor (H.F.M.)
}

\begin{abstract}
Two cold-recombinant influenza A (H1N1) viruses were tested in several groups of human volunteers. Only minor clinical symptoms were seen and no febrile reactions occurred. With serologically primed individuals virus shedding was low, but a high proportion showed rises in serum antibody levels after vaccination and mean titres were high. With serologically unprimed volunteers shedding was high, about $75 \%$ yielding viruses but only at low titres and for a short duration. No revertant viruses were found and there was no evidence of transmission to potentially susceptible individuals housed in close contact to the vaccinees.

Serum antibody responses with unprimed volunteers were, however, low. Only about one half showed increases in serum antibody titres after vaccination and mean titres were low. Nevertheless, challenge with live attenuated virus indicated a high degree of protection based on virological evidence of infection.
\end{abstract}

Key words: influenza, live vaccines, attenuation

\section{INTRODUCTION}

Previous studies [Maassab et al, 1972; Maassab et al, 1977; Maassab, 1975] have shown that the cold-adapted influenza A virus, A/AA/6/60 (H2N2) [Maassab, 1967; Kitayama et al, 1973] can be used to generate attenuated recombinant viruses for use as live-virus vaccine strains. We have described clinical trials in adults and children with a live-virus vaccine containing an A/Victoria/3/75 (H3N2) cold-recombinant virus. CR22 [Moritz et al, 1978]. With this recombinant reactogenicity was slight and serum antibody responses good, a high proportion of volunteers showing serum conversion.

Mean serum titres after vaccination with the live vaccine were high in accordance with the findings of others employing attenuated $\mathrm{H} 3 \mathrm{~N} 2$ influenza $\mathrm{A}$ virus recombinants [Huygelen et al, 1973; Hrabar et al, 1977; Murphy et al, 1978; Moffat et al, 1976; Rubin et al, 1976]. Studies with H3N2 viruses have all been made during the A/Hong Kong/78

Accepted for publication June 24, 1980.

Address reprint requests to P. Reeve, National Institute for Biological Standards, Holly Hill, Hampstead, London NW3 6RB, England. 
(H3N2) influenza drift period. All volunteer studies, therefore, would have been made with persons who were likely to have had previous infection with $\mathrm{H} 3 \mathrm{~N} 2$ viruses. Thus, even volunteers without detectable antibody to the A/Victoria/3/75 (H3N2) virus are likely to have been primed immunologically to H3N2 subtype viruses. Priming might have mediated the clinical response to live-virus vaccination, for example, by ameliorating residual virulence of an apparently attenuated strain. The serological responses seen might also have resulted from an amnestic response to previously encountered antigens. It was of great interest, therefore, to study the clinical and immunological responses to H1N1 virus recombinants. As strains of this subtype had not been epidemic since 1956, a substantial population of young adults existed with no previous exposure to such viruses. They would, therefore, be immunologically unprotected. Indeed, substantial outbreaks of influenza were reported in children and young adults between 1978 and 1979 [Zhadnov et al, 1978; Gregg et al, 1978]. We describe here the clinical, virological, and serological responses found in both primed and unprimed volunteers to two H1N1 cold-recombinant influenza viruses. We also show from subsequent challenge infections that such live-virus vaccination induces substantial protection for up to at least five months.

\section{MATERIALS AND METHODS}

\section{Viruses}

The origin and properties of the two viruses, recombiriant CR33 and recombinant BG12, will be described [Reeve et al, unpublished information]. The CR33 recombinant was derived by Professor Maassab in his laboratory in Michigan, by recombination between the A/AA/6/60 (H2N2) cold-adapted virus and the A/USSR/90/77 (H1N1) virus. This work was supported by the US government NAIAD contract No. 1-A1-72521. Subsequent preclinical and clinical studies with CR33 were performed at the Sandoz Research Institute, Vienna. The other recombinant, BG12, was derived in our laboratories by recombination between the A/AA/6/60 (H2N2) cold-adapted virus and the A/USSR/92/77 (H1N1) virus. The genes coding for HA, NA, and one of the P proteins of virus BG12 are derived from the wild-type virus. In the case of the CR33, only the genes coding for the surface antigens haemagglutinin (HA) and neuraminidase (NA) derive from the wild-type virus.

\section{Volunteers}

Volunteers for two studies were recruited from seronegative male or female university students aged 19 to 26 years who had given informed consent. Seronegative subjects were selected where serum haemagglutination inhibition (III) and serum neuraminidase inhibition (NI) titres were $<1: 8$ using an A/USSR/92/77 (H1N1) antigen. Pregnancy, current or recent upper respiratory tract infections, and known sensitivity to egg proteins were grounds for exclusion of volunteers from the study. The volunteers were given the following medical and clinical laboratory examinations before admission to the studies and excluded if abnormalities were detected: complete blood counts, chest X ray, blood chemistry (BUN, SGOT, SGPT, alkaline phosphatase, bilirubin, and fasting glucose levels), patellar tendon reflexes, and urinalysis. They were lodged at a sequestered wing of an hotel in the Vienna Woods in double and single rooms and so separated from the public. 
In a third trial, volunteers aged 30 to 46 years were employees of the Sandoz Research Institute.

Volunteer studies conformed to the guidelines for human experimentation, Declaration of Helsinki, and had received institutional and ethical approval.

\section{Initial Studies}

Three clinical trials have been made with adult volunteers. In two, volunteers were selected with no detectable serum HI, NI, or serum neutralising (SN) antibodies. Older volunteers (aged 30 years or more) participated in a trial concurrent with the second study, some possessing HI antibody. It is very likely that those older volunteers would have been "primed" to H1N1 subtype viruses by previous exposure before 1956. The trials were made in the Autumn of 1978. At this time there were no current epidemics of respiratory disease in Vienna.

Serum samples collected immediately before vaccination and three weeks thereafter, were assayed for HI or NI using techniques described [Kunz et al, 1977] and an A/USSR/92/77 (H1N1) antigen. SN antibodies were assayed using a plaque reduction assay and virus A/USSR/92/77 (H1N1).

\section{Challenge Studies}

Volunteers from the previous trials with young volunteers were asked to take part in a further trial in which their resistance to infection with the recombinant BG12 was tested. Challenge studies were made four months and five months, respectively, after the original vaccination studies. An additional age-matched unimmunised group was also included. A total of 52 volunteers were included in this study. All volunteers received 6.4 $\left(\log _{10}\right)$ EID $_{50}$ while the volunteer remained prone, head tilted back, for approximately one minute. Subsequently, every day for four days nasal swabs were obtained for virusisolation studies. Three weeks after the start of the challenge trial a further serum sample was taken for antibody determinations.

Virus isolations were made from material collected by nasal swabs using Eagle's minimal essential medium (MEM) containing $10 \%(v / v)$ tryptose phosphate broth as transport medium. On the same day of collection, swab material was inoculated into Madin Derby Canine Kidney (MDCK) cell cultures in the presence of MEM with 10 $\mu \mathrm{gm} / \mathrm{ml}$ trypsin for virus isolation [Oxford et al, 1979].

\section{RESULTS}

\section{Trials in Young Seronegative Adult Volunteers}

In both trials volunteers were inoculated intranasally with either recombinant CR33, recombinant BG12, or physiological saline. Inoculations were given in $0.4-\mathrm{ml}$ volumes according to a computer-generated randomisation list.

In the first trial, volunteers received $7.4\left(\log _{1_{0}}\right)$ EID $_{s_{0}}$ of virus vaccine or placebo. In the second trial a higher dosage was given and volunteers received either $8.6\left(\log _{10}\right)$ EID $_{50}$, recombinant BG12 or $8.7\left(\log _{10}\right)$ EID $_{50}$ recombinant CR33, or placebo.

\section{Clinical Reactions After Vaccination}

All reactions to vaccine or placebo were mild (Table I). The most frequently observed reactions to live-virus vaccine were slight "stuffy nose" or "running nose." With the first study five of 12 volunteers given recombinant CR33 and three of 12 given re- 
TABLE I. Clinical Responses of Young Adult Volunteers to Influenza A (HIN1) Recombinant Viruses*

\begin{tabular}{clccccc}
\hline Study No. & Vaccine & $\begin{array}{c}\text { Dose } \\
\left(\log _{10}\right) \\
\text { EID }_{50}\end{array}$ & $\begin{array}{c}\text { No, of } \\
\text { volunteers }\end{array}$ & $\begin{array}{c}\text { No, with } \\
\text { fever }\end{array}$ & $\begin{array}{c}\text { No. with afebrile } \\
\text { systemic reactions }\end{array}$ & $\begin{array}{c}\text { No. with upper } \\
\text { respiratory symptoms }\end{array}$ \\
\hline \multirow{2}{*}{1} & Placebo & 0 & 13 & 0 & 1 & 5 \\
& BG12 & 7.4 & 12 & 1 & 5 & 6 \\
& CR33 & 7.4 & 13 & 0 & 3 & 7 \\
2 & Placebo & 0 & 7 & 0 & 0 & 0 \\
& BG12 & 8.6 & 7 & 0 & 5 & 0 \\
\hline
\end{tabular}

*Fever was regarded as an oral temperature of $38^{\circ} \mathrm{C}$ or higher. Systemic reactions, headache, fatigue, muscular pains or weakness, were included when recorded as "moderate" on any one occasion or "slight" on at least two consecutive days. No "severe" reactions were seen. Upper respiratory tract reactions, cough, sore throat, stuffy or running nose are included using the same criteria.

combinant BG12 reported stuffy or running noses. One volunteer given recombinant CR33 reported a running nose, slight cough, and headache and one a stuffy nose and myalgia. A further volunteer given recombinant CR33 complained of headache and a running nose on the day of inoculation. With recombinant BG12 two volunteers with running noses complained of slight or moderate headaches. In this study five of 12 volunteers given placebo also complained of slight running or stuffy noses, two had coughs, and one a moderate headache.

In our second study with young volunteers a similar picture was seen. With recombinant CR22 three of seven had running or stuffy noses; with recombinant BG12 three of eight had running or stuffy noses and two in addition complained of slight sore throats. In this study no reactions were observed from the placebo group (Table I).

Two volunteers who had received recombinant BG12 showed transitory rises in body temperature on the second day after inoculation. The maximum recorded temperature being $38.9^{\circ} \mathrm{C}$ with one volunteer and $38.0^{\circ} \mathrm{C}$ with the other. All other volunteers recorded normal body temperatures.

A high proportion of volunteers shed viruses for up to seven days after inoculation (Table II). No viruses were isolated from the placebo groups, and no revertant viruses were found. It was evident from the virus isolations that most volunteers were infected with the live-recombinant viruses.

The serum antibody responses were low. Only a proportion of the volunteers showed increases in serum titres whether measured in the HI, NI, or SN tests. Increasing the dose inoculated did not markedly increase the number of volunteers showing seroconversion (Table II). The overall percentage of volunteers showing increases in serum titres was approximately 50\% and the mean serum HI titre was $1: 12$ (Table II).

\section{Effect of Second Vaccination}

The finding of low rates of seroconversion and low mean serum antibody titres prompted us to reinoculate the volunteers with one of several preparations. Firstly, we considered whether the low titres found were merely a response to the antigenic mass of 
TABLE II. Response to Intranasal Infection With Cold-Recombinant Influenza A (H1N1) Viruses*

\begin{tabular}{|c|c|c|c|c|c|c|c|c|}
\hline \multirow[b]{2}{*}{ Study No. } & \multirow[b]{2}{*}{ Vaccine } & \multirow{2}{*}{$\begin{array}{l}\text { Dose } \\
\left(\log _{10}\right) \\
\text { EID }_{50}\end{array}$} & \multirow{2}{*}{$\begin{array}{c}\text { No. of } \\
\text { Volunteers }\end{array}$} & \multicolumn{4}{|c|}{ Serum HI responses } & \multirow{2}{*}{$\begin{array}{l}\text { No. shedding } \\
\text { virus }\end{array}$} \\
\hline & & & & $<8$ & 8 & 16 & $>16$ & \\
\hline \multirow[t]{3}{*}{1} & Placebo & 0 & 13 & 11 & 2 & 0 & 0 & 0 \\
\hline & BG12 & 7.4 & 12 & 3 & 6 & 3 & 0 & 10 \\
\hline & CR33 & 7.4 & 13 & 3 & 6 & 3 & $1(32)$ & 10 \\
\hline \multirow[t]{3}{*}{2} & Placebo & 0 & 7 & 6 & 1 & 0 & 0 & 0 \\
\hline & BG12 & 8.6 & 8 & 3 & 3 & 1 & $1(512)$ & 6 \\
\hline & CR33 & 8.7 & 7 & 2 & 3 & 1 & $1(32)$ & 3 \\
\hline
\end{tabular}

*Seronegative volunteers under 20 years old were inoculated with either a recombinant virus or placebo in double-blind closed trials. Serum haemagglutination inhibition (HI) responses were measured to homologous antigens three weeks after infection. Before immunisation all volunteers had $\mathrm{HI}$ titres of $<1: 8$. Virus isolations were made from nasal swabs using MDCK cell cultures and Eagle's minimal essential medium containing $10 \mu \mathrm{gm} / \mathrm{ml}$ trypsin.

the locally applied virus. Accordingly, a group of volunteers previously inoculated with placebo material and a further group who had received live-recombinant BG12 were reinoculated by the intranasal route with a formalin-inactivated preparation of the recombinant BG12. None of the volunteers from either group showed a change in serum antibody titres, Table III. From this we concluded that the responses found were not due merely to the antigenic mass of the live-virus preparations. This experiment also showed that no booster type of response could be elicitated using killed vaccine intranasally. Volunteers from the group which had received recombinant CR33 were revaccinated with the subunit vaccine Sandovac ${ }^{\oplus}$ [Bachmayer et al, 1976; Kunz et al, 1977] containing $10 \mu \mathrm{g}$ A/USSR/90/77 (H1N1) per dose. After the booster immunization with Sandovac ${ }^{\circledR}$ one half $(55 \%)$ of the volunteers showed rises in serum HI titres and the GMT was 1:20, Table III. This response was not significantly higher than the response of unprimed individuals to a single dose of the subunit vaccine. In another at tempt to boost antibody responses, all of the volunteers from study No. 2 were inoculated intranasally with $8.1\left(\log _{10}\right)$ EID $_{50}$ recombinant BG12. The changes in serum titres observed did not differ from the immune response observed after the first dose of the vaccine (Table III).

\section{Trial in Volunteers "Primed" Against H1N1 Influenza}

To test the response to live vaccination with H1N1 influenza A viruses in primed individuals, eight volunteers over 30 years old were inoculated intranasally with 8.1 $\left(\log _{10}\right)$ EID $_{50}$ of the recombinant BGI2.

Four of the volunteers possessed initial titres of 1:8 or less: All showed twofold or greater rises in serum HI titres 38 days after vaccination. The mean titres were 1:22. The remaining four volunteers possessed initial titres of 1:16 or more. None showed significant rises in serum HI titres (Table IV).

\section{Challenge Trial}

From the control group of 11 unimmunised volunteers, seven shed viruses up to four days after infection. The maximum titre found was $4.0\left(\log _{10}\right) \mathrm{TCID}_{50}$ and the mean was $2.5\left(\log _{10}\right)$ TCID $_{50}($ Table V). 
TABLE III. Response to Reimmunisation With Live or Inactivated Cold-Recombinant Virus Given Intranasally or Parenteral Subunit Vaccine*

\begin{tabular}{|c|c|c|c|c|c|}
\hline \multirow[b]{2}{*}{ Study No. } & \multirow[b]{2}{*}{$\begin{array}{c}\text { First } \\
\text { Vaccine }^{\mathrm{a}}\end{array}$} & \multirow[b]{2}{*}{$\begin{array}{l}\text { Booster } \\
\text { Vaccine }^{a}\end{array}$} & \multirow[b]{2}{*}{$\begin{array}{l}\text { No. of } \\
\text { Volunteers }\end{array}$} & \multicolumn{2}{|c|}{$\begin{array}{l}\text { Serum HI responses } \\
\text { following booster vaccine }\end{array}$} \\
\hline & & & & $\begin{array}{l}\text { Percentage showing any } \\
\text { serum titre increases }\end{array}$ & $\begin{array}{l}\text { Reciprocal } \\
\text { mean titres }\end{array}$ \\
\hline \multirow[t]{3}{*}{1} & Placebo & $\begin{array}{c}\text { Inactivated } \\
\text { BG12 }\end{array}$ & 8 & 0 & 4 \\
\hline & BG12 & $\begin{array}{c}\text { Inactivated } \\
\mathrm{BG} 12\end{array}$ & 12 & 0 & 6 \\
\hline & CR33 & Sandovac ${ }^{\oplus}$ & 11 & 55 & 20 \\
\hline \multirow[t]{3}{*}{2} & Placebo & BG12 & 7 & 43 & 16 \\
\hline & BG12 & BG12 & 5 & 0 & 33 \\
\hline & CR33 & BG1 2 & 6 & 17 & 9 \\
\hline
\end{tabular}

${ }^{a}$ All vaccines administered intranasally. Only Sandovac given IM/SC.

*Volunteers from previous studies (Table I) were reimmunised with the preparation indicated. Volunteers in study No. 2 received $8.1\left(\log _{10}\right)$ EID $_{50}$ recombinant BG12 as a booster inoculation. Serum haemagglutination inhibition (HI) responses were measured using homologous antigens three weeks after booster inoculation.

TABLE IV, Response of "Primed" Individuals to Intranasal Infection With a Cold-Recombinant Influenza A (H1N1) Virus*

Reciprocal serum HI titre

\begin{tabular}{|c|c|c|c|}
\hline & & & \\
\hline & Volunteer No. & Before vaccination & After vaccination \\
\hline Volunteers with HI titres of & 30 & $<8$ & 8 \\
\hline$\leqslant 1: 8$ before vaccination & 33 & $<8$ & 32 \\
\hline & 32 & 8 & 32 \\
\hline & 25 & 8 & 16 \\
\hline Mean titre & & 6 & 22 \\
\hline Volunteers with HI titres of & 34 & 16 & 32 \\
\hline$>1: 8$ before vaccination & 31 & 64 & 64 \\
\hline & 36 & 64 & 64 \\
\hline & 37 & 128 & 256 \\
\hline Mean titre & & 68 & 104 \\
\hline
\end{tabular}

\footnotetext{
*Volunteers over 30 years old were infected with $8.1\left(\log _{10}\right) \mathrm{EID}_{50}$ of the recombinant BG12. Serum
} HI responses were measured before and three weeks after infection. 


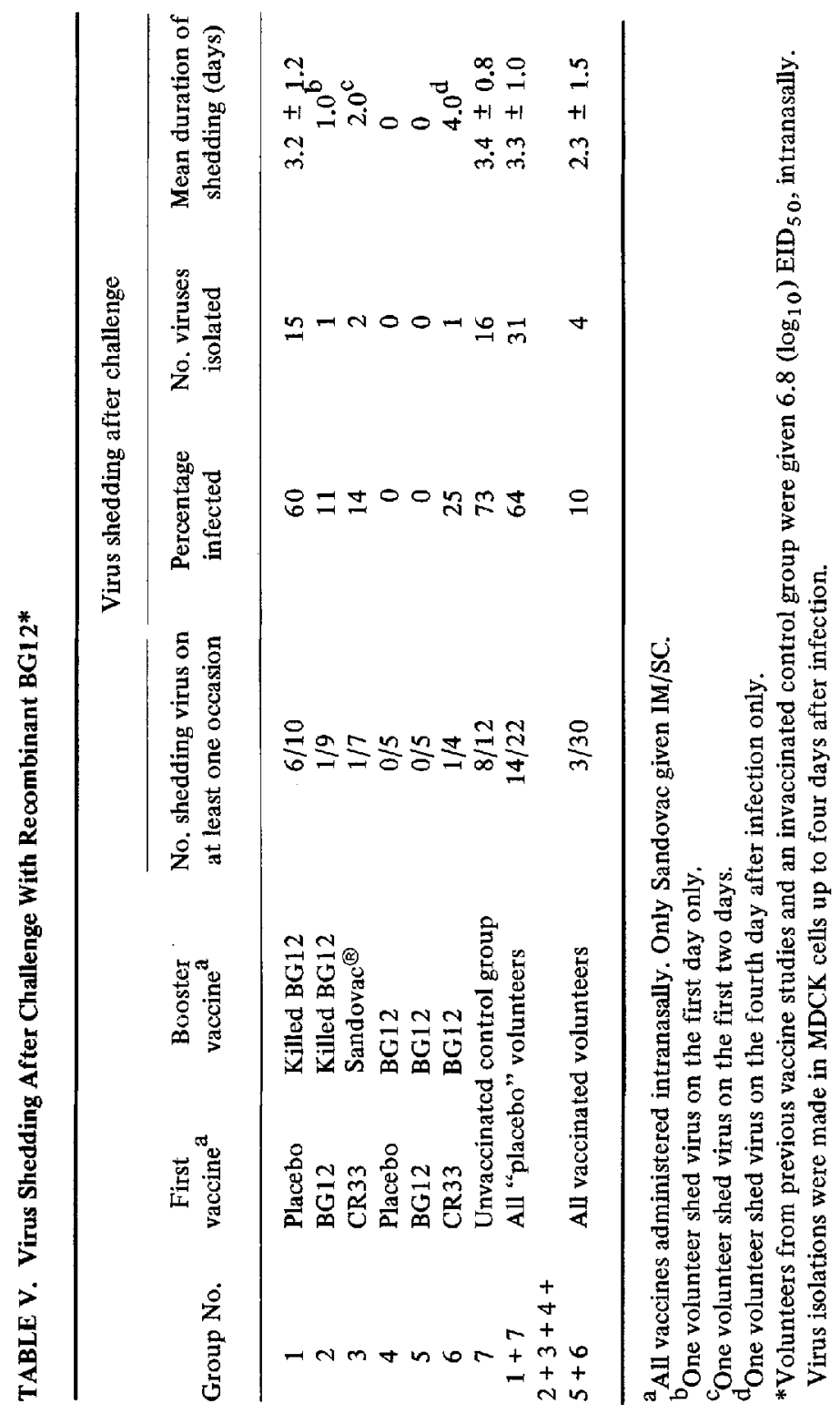


A similar shedding pattern was found with the ten volunteers given placebo in a first trial made five months before the challenge study. Six of the ten shed viruses for as long as four days. The maximum titre was $4.0\left(\log _{10}\right)$ TCID 50 and the mean was $2.2\left(\log _{10}\right)$ $\mathrm{TCID}_{50}($ Table V). The overall infection rate of both "unprotected" groups was $64 \%$. From the volunteers previously vaccinated with recombinant BG12, CR33, or both viruses, only three virus isolations were obtained from a total number of 30 volunteers (Table V). Thus, previous vaccination with live-virus vaccine induced a highly significant degree of protection in comparison with the control groups $(P \leqslant 0.001)$. The numbers of volunteers in each group was small and so it is not possible to compare the efficacy of the different vaccination schedules used. But there was no major difference between volunteers immunized four months or five months before challenge. The viruses reisolated proved antigenically identical to A/USSR/92/77 (H1N1) in HI tests.

\section{DISCUSSION}

When young double-seronegative and "unprimed" volunteers were infected with cold-recombinant influenza A viruses of the subtype H1N1, a high proportion were infected as judged from virus shedding. Despite prolonged virus shedding, serum antibody responses were poor. Only a proportion showed changes in serum HI or SN titres and mean titres were low. We concluded that the serological response which we could detect was due to infection since intranasal administration of homologous-killed antigen to unimmunised volunteers did not induce any immune response at all. We could not boost the immune response to H1N1 viruses after vaccination with live, attenuated viruses by killed-virus antigen applied intranasally or by subsequent intranasal inoculation with live, attenuated virus.

The poor immune response was not due, however, to a defect in the antigenicity of the recombinants. Both induced, high titres of circulatory antibody in hamsters infected intranasally [Reeve et al, unpublished information]. Additionally, good immune responses were seen in the volunteers from the higher age group where the response was similar to that found with a cold-recombinant H3N2 influenza virus [Moritz et al, 1978] .

The serum antibody levels found in the younger volunteers would give no evidence of protection against infection with homologous virus. Hobson [Hobson et al, 1972] from a challenge study of volunteers previously immunized with a killed-influenza (H3N2) vaccine estimated the $50 \%$ protective antibody level to be $1: 36$. In our studies with live $\mathrm{H} 1 \mathrm{~N} 1$ influenza virus vaccines in unprimed persons, such serum $\mathrm{HI}$ titres were not achieved even after booster vaccinations. We could not, therefore, conclude from serological results that vaccination of unprimed persons with the live $H 1 N 1$ vaccines would confer protection against reinfection. A challenge study, however, using live attenuated virus subsequently demonstrated a highly significant degree of protection four and five months after vaccination. 


\section{REFERENCES}

Bachmayer H, Liehl E, Schmidt G (1976): Preparation and properties of a novel influenza subunit vaccine. Postgraduate Medical Journal 52:360.

Gregg MB, Hinman AR, Craven RB (1978): The Russian flu: Its history and implications for this year's influenza season. Journal of the American Medical Association 240:2260.

Hobson D, Curry RL, Beare AS, Ward-Gardner A (1972): The role of serum haemagglutination-inhibiting antibody in protection against challenge infection with influenza A2 and B viruses. Journal of Hygiene $70: 767$.

Hrabar A, Vodopija I, André FE, Mitchell JR, Maassab HF, Hennessy AV, Davenport FM (1977): A placebo-controlled dose response study of the reactogenicity and immunogenicity of a cold-adapted recombinant $A / V$ ictoria/3/75 live influenza virus candidate vaccine in healthy volunteers. Developments in Biological Standardization 39:53.

Huygelen C, Peetermans J, Vascoboinic E, Berge E, Colinet G (1973): Live attenuated influenza virus vaccine: In vitro and in vivo properties. Symposium on Influenza Vaccines for Men and Horses. Symposium Series Immunobiological Standardization 20:152.

Kitayama T, Togo Y, Hornick RB, Friedwald WT (1973): Low-temperature-adapted influenza AZ/AA/ $6 / 60$ virus vaccine in man. Infection and Immunity 7:119.

Kunz C, Hofmann H, Bachmayer H, Liehl E, Moritz AJ (1977): Clinical trials with a new influenza subunit yaccine in adults and children. Developments in Biological Standardization 39:297.

Maassab HF (1967): Adaptation and growth characteristics of influenza virus at $25^{\circ} \mathrm{C}$. Nature 213:612.

Maassab HF (1975): Properties of influenza virus "cold" recombinants. In Mahy BWJ, Barry RD (eds): "Negative Strand Viruses." New York: Academic Press, vol 2, p 755.

Maassab HF, Cox NJ, Murphy BR, Kendal AP (1977): Biological, genetic and biochemical characterization of a cold-adapted recombinant $A / V i c t o r i a / 3 / 75$ virus and its evaluation in volunteers. Developments in Biological Standarization 39:25.

Maassab HF, Kendal AP, Davenport FM (1972): Hybrid formation of influenza virus at 25. Proceedings of the Society for Experimental Biology and Medicine, New York 139:768.

Maffat MAJ, Stealey VM, Freestone DS, MacDonald A (1976): Assessment of elicited antibody responses, clinical reactions and transmissibility of WRL 105 live influenza vaccine. Journal of Biological Standardization 4:91.

Moritz AJ, Kunz C, Hofmann H, Reeve P, Maassab HF, Bachmayer H, Liehl E (1978): Evaluation of a cold recombinant $A /$ Victoria/3/75 virus in adult volunteers. Fourth International Congress of Virology.

Murphy BR, Markoff LJ, Hosier NT, Rusten HM, Chanock RM, Kendal AP, Douglas RG, Betts RF, Cate TR Jr, Couch RB, Levine MM, Waterman DH, Holley HP Jr (1978): Temperature-sensitive mutants of influenza $A$ virus: Evaluation of A/Victoria/3/75-ts-1(E) recombinant viruses in volunteers. Infection and Immunity 20:671.

Oxford JS, Corcoran T, Schild GC (1980): Naturally occurring temperature-sensitive influenza A viruses of the H1N1 and H3N2 subtypes. Journal of General Virology 383-389.

Rubin RJ, Noble GR, Corey L, Brown WJ Jr, Brandling-Bennett D, Kaye HS, Coleman MT, Gregg MB, Dowdle WR (1976): Live attenuated influenza A/England/42/72 (H3N2) virus vaccine: A field trial. Journal of Infectious Diseases 133:613.

Zhdanov VM, Zakstelskaya LY, Isachenko VI, Reznik VI, Andreyev VP, Lvov DK, Yakhno MA, Braude NA, Pysina TV, Podchernyaeva TY (1978): Return of epidemic A1 (H1N1) influenza virus. Lancet 1:294. 